\title{
ANALISIS MOTIVASI BERWIRAUSAHA MAHASISWA PADA PROGRAM STUDI PENDIDIKAN AKUNTANSI FKIP UNIVERSITAS PGRI PALEMBANG
}

\author{
Oleh: Riswan Aradea \\ (UNIVERSITAS PGRI PALEMBANG)
}

riswanaradea@gmail.com

\begin{abstract}
Abstrak-Banyak faktor yang dapat mempengaruhi motivasi berwirausaha mahasiswa. diantaranya adalah kemampuan mahasiswa beradaptasi dengan kondisi perubahan lingkungan, baik internal maupun eksternal. Penelitian ini bertujuan untuk melihat motivasi berwirausaha mahasiswa dengan cara mendeskrifsikan motivasi berwirausaha mahasiswa pada program studi Pendidikan Akuntansi FKIP Universitas PGRI Palembang. Penelitian ini menggunakan metode desktiptif analitik, untuk mendapatkan data yang akurat peneliti ini, peneliti menggunakan dokumentasi dan angket, angket di berikan kepada Mahasiswa program Studi Pendidikan Akuntansi FKIP Universitas PGRI Palembang. Berdasarkan hasil analisa data angket, maka dapat disimpulkan bahwa: Motivasi Berwirausaha Mahasiswa pada Program Studi Pendidikan Akuntansi FKIP Universitas PGRI Palembang dalam Kategori Baik / Tinggi, dengan rata-rata yaitu sebesar 80,79. Indikator yang paling mendasari motivasi berwirausaha mahasiswa Program Studi Pendidikan Akuntansi adalah Indikator Tanggung jawab mahasiswa dalam mengerjakan tugas mata kuliah kewirausahaan yaitu sebesar 84,07\% dalam Kategori Sangat Baik.
\end{abstract}

Kata Kunci: Deskripsi, Motivasi, Berwirausaha

\begin{abstract}
Factors can affect student entrepreneur motivation. is the ability of students to adapt to environmental change conditions, both internal and external. This study aims to see the motivation of student entrepreneurship by way of describing the entrepreneurship motivation of students in Accounting Education Program FKIP Universitas PGRI Palembang. This study uses descriptive analytic method, data obtained by researchers, researchers using documentation and questionnaires, questionnaires among students of Accounting Education Studies Program FKIP University PGRI Palembang. Based on the results of questionnaire data analysis, it can be concluded: Student Entrepreneur Motivation in Accounting Education Studies Program FKIP University PGRI Palembang in Category Good / High, with an average of 80.79. The most underlying indicator of entrepreneurship motivation of students of Accounting Education Study Program is Indicator Student responsibility in doing entrepreneurship subject task that is equal to 84,07\% in Very Good Category.
\end{abstract}

Keywords: Description, Motivation, Entrepreneurship 


\section{PENDAHULUAN}

Sedikitnya lapangan pekerjaan yang ada saat ini, menjadi alasan utama bertambahnya pengangguran di negara ini, dan juga ada beberapa pabrik atau industri yang banyak merumahkan karyawannya karena mengalami kebangkrutan. Kondisi ini dapat dikurangi jika kita berusaha menciptakan lapangan pekerjaan sendiri. Untuk itu semua masyarakat khususnya kalangan mahasiswa yang memiliki kreatifitas dan bekal ilmu yang telah diperolehnya di dunia perkuliahan, sebaiknya memiliki mental untuk berwirausaha dibanding menggantungkan diri dengan berburu pekerjaan bersama jutaan pengangguran yang juga mencari kerja.

Menurut Suryana (2011:3) Proses kewirausahaan diawali dengan suatu aksioma, yaitu adanya tantangan. Dari tantangan tersebut timbul gagasan, kemauan dan dorongan untuk berinisiatif, yang tidak lain adalah berfikir kreatif dan bertindak inovatif, sehingga tantangan awal tadi teratasi dan terpecahkan. Intinya tidak ada tantangan tidak akan kreatif, dan tidak kreatif tidak akan ada tantangan.

Bagi mahasiswa yang ingin menciptakan wirausaha, mahasiswa itu sendiri harus meminimal mungkin mengetahui dunia berwirausaha. Untuk itu semua kalangan mahasiswa yang memiliki kreatifitas dan bekal ilmu yang telah diperolehnya di dunia perkuliahan, sebaiknya memiliki mental untuk berwirausaha dibanding menggantungkan diri dengan berburu pekerjaan bersama jutaan pengangguran yang juga mencari kerja. Belakangan ini banyak pihak yang menyelenggarakan seminar, workshop maupun pelatihan dan pengembangan motivasi berwirausaha di kalangan mahasiswa.

Banyak faktor yang dapat mempengaruhi motivasi berwirausaha mahasiswa. diantaranya adalah kemampuan mahasiswa beradaptasi dengan kondisi perubahan lingkungan, baik internal maupun eksternal. Dengan demikian masalah yang akan dibahas dalam penelitian ini akan diurai berdasarkan pertanyaan "Apakah yang mendasari motivasi berwirausaha mahasiswa pada program studi Pendidikan Akuntansi FKIP Universitas PGRI Palembang?". Penelitian ini bertujuan untuk melihat motivasi berwirausaha mahasiswa dengan cara mendeskrifsikan motivasi berwirausaha mahasiswa pada program studi Pendidikan Akuntansi FKIP Universitas PGRI Palembang. Berdasarkan latar belakang tersebut diataslah, peneliti merasa perlu meneliti dengan judul: Analisis Motivasi Berwirausaha Mahasiswa pada Program Studi Pendidikan Akuntansi FKIP Universitas PGRI Palembang. 


\section{TINJAUAN PUSTAKA \\ Pengertian Motivasi}

Istilah motivasi berasal dari kata motif yang dapat diartikan sebagai kekuatan yang terdapat pada diri individu, yang menyebabkan individu tersebut bertindak atau berbuat. Motif adalah daya penggerak dalam diri seseorang untuk melakukan aktivitas tertentu, demi mencapai tujuan tertentu. Menurut Uno (2007: 3) mengatakan bahwa motivasi merupakan dorongan yang terdapat dalam diri seseorang untuk berusaha mengadakanperubahan tingkah laku yang lebih baik dalam memenuhi kebutuhannya.

Pada hakikatnya motivasi adalah dorongan internal dan eksternal pada siswa yang sedang belajar untuk mengadakan perubahan tingkah laku pada umumnya dengan beberapa indikator yaitu:

a. Adanya hasrat dan keinginan berhasil.

b. Adanya dorongan dan kebutuhan dalam belajar.

c. Adanya harapan dan cita-cita masa depan.

d. Adanya penghargaan dalam belajar.

e. Adanya kegiatan yang menarik dalam belajar.

f. Adanya lingkungan belajar yang kondusif sehingga memungkinkan seseorang siswa dapat belajar dengan baik.

Pembuatan individu muncul dikarenakan motif instrinsik dan motif ekstrinsik. Motif instrinsik adalah prilaku yang disebabkan oleh motif yang muncul tampa perlu adanya ganjaran atas perbuatan, dan tidak perlu hukuman untuk tidak melakukannya. Sedangkan motif ekstrinsik adalah prilaku individu yang hanya muncul karena adanya hukuman.

\section{Pengertian Kewirausahaan}

Menurut Dhewanto (2013: 5) mengatakan Intrapreneurship atau yang biasa juga dikenal dengan kewirausahaan sudah dikenal dan diaplikasikan baik oleh perusahaan publik maupun perusahaan swasta diseluruh dunia, berkembang mulai dari Amerika Serikat, Eropa, Afrika hingga Asia. Konsep dasar dari Intrapreneurshipdi dalam perusahaan dengan cara mendorong proses inovasi kepada para karyawan.

Dalam lampiran Keputusan Menteri Koperasi dan Pembinaan Pengusahan Kecil Nomor 961/KEP/M/XI/1995, dicantumkan bahwa:

1. Wirausaha adalah orang yang mempunyai semangat, sikap, perilaku dan kemampuan kewirausahaan.

2. Kewirausahaan adalah semangat, sikap, perilaku dan kemampuan seseorang dalam menangani usaha atau kegiatan yang mengarah pada upaya mencari, menciptakan serta menerapkan cara kerja, teknologi dan produk baru dengan meningkatkan efisiensi dalam 
rangka memberikan pelayanan yang lebih baik dan atau memperoleh keuntungan yang lebih besar. Jadi wirausaha itu mengarah kepada orang yang melakukan usaha/kegiatan sendiri dengan segala kemampuan yang dimilikinya. Sedangkan kewirausahaan menunjuk kepada sikap mental yang dimiliki seorang wirausaha dalam melaksanakan usaha/kegiatan.

Selain memiliki berbagai pengertian, wirausaha juga mempunyai 3 tema penting yang perlu di terapkan dalam melakukan wirausaha. Berikut adalah tiga tema wirausaha (Suryana,2011: 12):

1. Pursuit of opportunities, (entrepreneurship adalah berkenaan dengan mengejar kecenderungan dan perubahanperubahan lingkungan yang orang lain tidak melihat dan memperhatikannya).

2. Innovation, (entrepreneurship mencakup perubahan perombakan, pergantian bentuk, dan memperkenalkan pendekatanpendekatan baru (yaitu produk baru atau cara baru dalam melakukan bisnis).

3. Growth (pasca entrepreneur mengejar pertumbuhan, mereka tidak puas dengan tetap kecil atau tetap dengan ukuran yang sama. Entrepreneur menginginkan bisnisnya tumbuh dan bekerja keras untuk meraih pertumbuhan sambil secara berkelanjutan mencari kecenderungan dan terus melakukan innovasi produk dan pendekatan baru .

Dari beberapa konsep yang ada pada 6 hakekat penting kewirausahaan sebagai berikut (Suryana,2011 : 13) yaitu :

1. Kewirausahaan adalah suatu nilai yang diwujudkan dalam perilaku yang dijadikan dasar sumber daya, tenaga penggerak, tujuan, siasat, kiat, proses, dan hasil bisnis.

2. Kewirausahaan adalah suatu kemampuan untuk menciptakan sesuatu yang baru dan berbeda (ability to create the new and different).

3. Kewirausahaan adalah suatu proses penerapan kreativitas dan inovasi dalam memecahkan persoalan dan menemukan peluang untuk memperbaiki kehidupan.

4. Kewirausahaan adalah suatu nilai yang diperlukan untuk memulai suatu usaha (start-up phase) dan perkembangan usaha (venture growth).

5. Kewirausahaan adalah suatu proses dalam mengerjakan sesuatu yang baru (creative), dan sesuatu yang berbeda (inovative) yang bermanfaat memberi nilai lebih.

6. Kewirausahaan adalah usaha menciptakan nilai tambah dengan jalan mengkombinasikan sumbersumber melaui cara-cara baru dan berbeda untuk memenangkan persaingan. Nilai tambah tersebut 
dapat diciptakan dengan cara mengembangkan teknologi baru, menemukan pengetahuan baru, menemukan cara baru untuk menghasilkan barang dan jasa yang baru yang lebih efisien, memperbaiki produk dan jasa yang sudah ada, dan menemukan cara baru untuk memberikan kepuasan kepada konsumen.

Kompensasi merupakan motivator utama dalam kegiatan kewirausahaan. Kompensasi tidak selalu berbentuk uang, namun menurut Milkovich dan Newman dalam Dhewanto (2013:122) kompensasi dibagi menjadi 3 kategori yaitu:

a. Bayaran tidak langsung, seperti pelayanan dan keuntungan.

b. Bayaran langsung, seperti gaji dan insentif.

c. Bentuk relasional, seperti pengakuan, status dan keamanan.

Beberapa prinsip yang harus diikuti dalam pengembangan dan mempertahankan kewirausahaan di dalam organisasi menurut Morris dan Kuratko dalam Dhewanto (2013: 8) :

a. Secara selektif melakukan rotasi jabatan untuk mengekspos manajer dengan teritorial bisnis yang baru untuk menstimulasi munculnya peluang baru.

b. Alokasi sumber dana harus berlapis/memiliki tahapan.

c. Komitmen terhadap enterpreneurship harus jelas dalam praktisk kepemimpinan. d. Tidak semua ide akan menjadi nomor satu, tetapi belajar dari eksperimen yang ada dan percaya dengan kemampuan orang.

\section{METODELOGI PENELITIAN Variabel Penelitian}

Menurut Sugiyono (2014: 61) "Variabel penelitian adalah suatu atribut atau sifat atau nilai dari orang, obyek atau kegiatan yang mempunyai variasi tertentu yang ditetapkan oleh peneliti untuk dipelajari dan kemudian ditarik kesimpulannya". Sedangkan menurut Arikunto (2014: 169) "Variabel penelitian adalah gejala yang bervariasi, yang menjadi objek penelitian". Berdasarkan pendapat tersebut, maka varibael penelitian ini adalah Variabel tunggal yaitu: Studi Deskripsi Motivasi Berwirausaha Mahasiswa pada Program Studi Pendidikan Akuntansi FKIP Universitas PGRI Palembang

\section{Definisi Operasional Istilah}

Berdasarkan keterangan di atas, definisi operasional variabel dapat didefinisikan sebagai berikut:

a. Motivasi yaitu dorongan dalam diri seseorang untuk melakukan perubahan kearah yang lebih baik.

b. Kewirausahaan merupakan suatu kreatifitas mengembangkan atau menciptakan sesuatu yang baru.

\section{Tempat dan Waktu Penelitian}

Penelitian ini, dilakukan peneliti di Universitas PGRI 
Palembang, yang berada di Jl. Jend. A. Yani Lrg. Gotong Royong 9/10 Ulu Palembang. Penelitian ini dilakukan di semester 7 yaitu kelas 7.A dan 7.B, Program Studi Pendidikan Akuntansi Universitas PGRI Palembang tahun akademi 2017/2018.

\section{Metode Penelitian}

Penelitian ini menggunakan metode desktiptif. Adapun pengertian dari metode deskriptif menurut Sugiyono (2014: 29) adalah : "Metode Deskriptif adalah suatu metode yang berfungsi untuk mendeskripsikan atau memberi gambaran terhadap objek yang diteliti melalui data atau sampel yang telah terkumpul sebagaimana adanya tanpa melakukan analisis dan membuat kesimpulan yang berlaku untuk umum !". Untuk mendapatkan data yang akurat peneliti ini, peneliti menggunakan dokumentasi dan angket, angket di berikan kepada Mahasiswa program Studi Pendidikan Akuntansi FKIP Universitas PGRI Palembang.

\section{Populasi dan Sampel}

\section{Populasi}

Menurut Arikunto (2014, 173) "Populasi adalah keseluruhan subjek penelitian". Sedangkan menurut Sugiyono (2014, 117) "Populasi adalah wilayah generalisasi yang terdiri atas: obyek/subyek yang mempunyai kualitas dan karakteristik tertentu yang ditetapkan oleh peneliti untuk dipelajari dan kemudian ditarik kesimpulannya". Populasi dalam penelitian ini yaitu seluruh mahasiswa Program Studi Pendidikan Akuntansi Universitas PGRI Palembang tahun akademi 2017/2018 yang berjumlah 51 orang, yang dapat dilihat pada tabel berikut ini:

Tabel 1. Populasi Penelitian

\begin{tabular}{|c|c|c|c|c|}
\hline \multirow{2}{*}{ No } & \multirow{2}{*}{ Kelas } & \multicolumn{2}{|c|}{ Jenis Kelamin } & \multirow{2}{*}{ Jumlah } \\
\cline { 3 - 5 } & & Laki-Laki & Perempuan & \\
\hline 1 & Semeter 7. A & 3 & 24 & 27 \\
\hline 2 & Semeter 7. B & 6 & 18 & 24 \\
\hline & & 9 & 42 & 51 \\
\hline
\end{tabular}

Sumber: Program Studi Pendidikan Akuntansi Tahun 2017

\section{Sampel}

Menurut Arikunto (2014, 174) "Sampel adalah sebagian atau wakil populasi yang diteliti”. Sedangkan menurut Sugiyono (2014:118) "Sampel adalah bagian dari jumlah dan karakteristik yang dimiliki oleh populasi tersebut". Berhubungan dengan jumlah populasi yang sedikit, maka penelitian ini menggunakan sampel populasi, dimana seluruh populasi 
digunakan menjadi sampel. Adapun Sampel dalam penelitian ini adalah sebanyak 51 orang yang terdiri dari 2 semester yaitu semester 7, dikarenakan semester 7 telah belajar Mata Kuliah kewirausahan.

\section{Teknik Pengumpulan Data}

\section{Dokumentasi}

Menurut Arikunto (2014:274) "Metode dokumentasi yaitu mencari data mengenai hal-hal atau variabel yang berupa catatan, transkrip, buku surat kabar, majalah, prasasti, notulen rapat, legger dan agenda". Dalam penelitian ini teknik dokumentasi digunakan peneliti untuk memperoleh data secara umum yaitu keadaan mahasiswa, hasil belajar mahasiswa, keadaan dosen, Perguruan Tinggi tempat penelitian dan lainnya.

\section{Angket}

Menurut Arikunto (2014: 194) mengatakan bahwa angket adalah sejumlah pertanyaan tertulis yang digunakan untuk memperoleh informasi dari responden dalam arti laporan tentang pribadinya, atau halhal yang ia ketahui. Menurut Sugiyono (2010: 199) menyatakan bahwa metode angket adalah teknik pengumpulan data yang dilakukan dengan cara memberi seperangkat pertanyaan atau pertanyaan tertulis kepada responden untuk dijawab.

Angket yang digunakan dalam penelitian ini adalah angket tertutup,artinya angket ini diberikan langsung kepada responden untuk diminta jawaban. Alternatif jawaban dalam angket ini ada empat yaitu:

Tabel 2. Skor Angket

\begin{tabular}{|l|c|c|}
\hline \multirow{2}{*}{\multicolumn{1}{|c|}{ Pernyataan }} & \multicolumn{2}{c|}{ SKOR } \\
\cline { 2 - 3 } & Positif & Negarif \\
\hline Bila Sangat Setuju & 4 & 1 \\
\hline Bila Setuju & 3 & 2 \\
\hline Bila Kurang Setuju & 2 & 3 \\
\hline Tidak Setuju & 1 & 4 \\
\hline
\end{tabular}

Sugiyono (2010: 199)

Adapun kisi-kisi angketnya adalah

sebagai berikut: 
Tabel 3. Kisi-Kisi Angket

\begin{tabular}{|c|l|}
\hline \multicolumn{1}{|c|}{ Dimensi } & \multicolumn{1}{c|}{ Indikator } \\
\hline \multirow{4}{*}{ Motivasi Internal } & $\begin{array}{l}\text { Tanggung jawab mahasiswa dalam mengerjakan tugas mata } \\
\text { kuliah kewirausahaan. } \\
\text { Melaksanakan tugas kewirausahaan dengan target yang jelas. } \\
\text { Memiliki tujuan yang jelas dan menantang. } \\
\text { Ada umpan balik atas hasil belajar kewirausahaan. } \\
\text { Memiliki rasa senang dalam belajar kewirausahaan. } \\
\text { Selalu berusaha mengungguli orang lain. } \\
\text { Diutamakan prestasi dari apa yang telah dipelajari. }\end{array}$ \\
\hline \multirow{3}{*}{ Motivasi eksternal } & $\begin{array}{l}\text { Selalu berusaha memenuhi kebutuhan belajar kewirausahaan. } \\
\text { Senang memperoleh pujian dari prestasi belajar } \\
\text { Belajar dengan harapan ingin memperoleh prestasi } \\
\text { Belajar dengan harapan ingin memperoleh penghargaan dari } \\
\text { dosen. }\end{array}$ \\
\hline
\end{tabular}

Sumber: Dari Olahan Hasil Penelitian

\section{Instrumen Penelitian}

Angket dalam penelitian ini peneliti ambil semua karena Angket yang di uji cobakan kepada program studi pendidikan Geografi sebanyak 30 mahasiswa, yaitu 35 pernyataan tersebut Valid, jadi peneliti menggunakan semua pernyataan angket tersebut sebagai Angket penelitian yang di berikan kepada Mahasiswa Program Studi Pendidikan Akuntansi.

Teknik Analisis Data Analisis Deskriptif Data Angket

\section{Adapun cara-cara yang} dilakukan dalam analisis deskriptif adalah sebagai berikut:

a. Memberi skor pada jawaban siswa dengan ketentuan sebagai berikut:

1. Bila Sangat Setuju tampak skor 4

2. Bila Setuju tampak skor 3

3. Bila Kurang Setuju tampak skor 2

4. Tidak Setuju tampak skor 1

b. Menentukan nilai akhir (NA) berdasarkan skor yang diperoleh dengan ketentuan sebagai berikut:

$$
\mathrm{NA}=\frac{\text { Skor yang didapat }}{\text { skor maksimal }} \times 100
$$

Tabel 4. Kategori Persentase Angket

\begin{tabular}{|c|c|c|}
\hline No & Interval & Kategori \\
\hline 1. & $81-100$ & Baik sekali \\
2. & $76-85$ & Baik \\
3. & $60-75$ & Cukup \\
4. & $55-59$ & Kurang \\
5. & $\leq 54$ & Sangat kurang \\
\hline
\end{tabular}

(Purwanto, 2013:103) 


\section{HASIL DAN PEMBAHASAN \\ Diskripsi Umum Universitas PGRI Palembang}

Keberadaan

Persatuan Guru Republik Indonesia (PGRI) Palembang sudah dirasakan dalam kawasan regional maupun nasional. Alumni sudah tersebar di berbagai pelosok Sumatera Selatan dan Bangka Belitung serta beberapa provinsi terdekat lain seperti Bengkulu, Lampung dan Jambi sebagai tenaga pengajar tingkat SLTP, SLTA, perguruan tinggi, maupun sebagai tenaga struktural pada instansi pendidikan. Lulusan dari Universitas PGRI Palembang tidak hanya bekerja di dunia pendidikan saja, tetapi ada yang menjadi pegawai negeri maupun suwasta sampai ada yang menjadi wirausaha.

Ide pendirian Universitas PGRI Palembang di mulai pada tahun akademik 1984/1985 dengan nama Sekolah Tinggi Keguruan dan Ilmu Pendidikan (STKIP) Persatuan Guru Republik Indonesia (PGRI) Palembang. Sekolah Tinggi tersebut seperti halnya Fakultas Keguruan dan Ilmu Pendidikan di Perguruan Tinggi Negeri ataupun Perguruan Tinggi Swasta lainnya mengkonsentrasikan diri pada proses pencetakan tenaga pendidik. Secara formal Sekolah Tinggi Keguruan dan Ilmu Pendidikan PGRI Palembang ini ditetapkan berdasarkan Surat Izin Kopertis No.035/1984.

Pergantian status dari sekolah tinggi menjadi Universitas membuat pengembangan lebih jauh dengan, berdirinya 4 (empat) Fakultas disamping Fakultas Keguruan dan Ilmu Pendidikan (FKIP), yaitu Fakultas Matematika dan Ilmu Pengetahauan Alam (FMIPA), Fakultas Teknik (FT), Fakultas Ekonomi (FE), dan Fakultas Perikanan (F.Perikanan).

$\begin{array}{rcr}\text { Pada } & \text { tahun akademik } \\ \text { 2007/2008 } & \text { Universitas } & \text { PGRI }\end{array}$
Palembang telah memiliki 5 (lima) fakultas, 1 (satu) program pascasarjana 16 (enam belas) jurusan, dan 21 (dua satu) program studi. Perubahan status perguruan tinggi yang telah berjalan selama 7 (tujuh) tahun akademik tersebut membawa berbagai konsekuensi dalam pengembangannya lebih jauh, baik secara akademik maupun administrasi. Berbagai upaya dilakukan untuk menunjang pengembangan tersebut, baik peningkatan tenaga akademik, pelayanan adminstrasi dan keuangan, serta sarana prasarana yang semuanya mengarah pada proses peningkatan kualitas sumber daya manusia dan pembangunan secara fisik di Universitas PGRI Palembang. Seiring dengan peningkatan jumlah mahasiswa, maka peningkatan jumlah tenaga pengajar terus diupayakan, baik dalam jumlah maupun kualitasnya, serta penambahan dan perluasan 
gedung kuliah dan sarana pendukung lainnya.

Walaupun sejumlah upaya sudah dilakukan oleh Universitas PGRI Palembang untuk meningkatkan kualitas manajemen sumber daya manusia, kualitas layanan administrasi, kualitas pembelajaran, dan mutu lulusan, namun secara keseluruhan masih jauh dari sempurna. Dalam perspektif manajemen mutu, Universitas PGRI Palembang harus memiliki lembaga penjamin mutu yang berfungsi untuk mengendalikan mutu pendidikan yang mencakup mutu input, proses, output dan kepuasan pelanggan dan Stakeholders. Perbaikan mutu pendidikan yang selama ini telah dilakukan oleh Universitas PGRI Palembang perlu terus dikembangkan dan dikelola dengan baik dalam rangka manajemen mutu, baik atas inisiatif sendiri maupun melibatkan pihak luar. Untuk mewujudkan tuntutan pelangggan dan Stakeholders tersebut, Alhamdulillah telah terbentuk Lembaga Penjamin Mutu Pendidikan (LPMP) Universitas PGRI Palembang yang dibentuk melalui Surat Keputusan YPLP PT-PGRI Palembang No. : 113/C.1/YPLP PTPGRI/2009, tanggal 5 Februari 2009 dan Surat Keputusan Rektor Universitas PGRI Palembang No.090/R.C.2/Univ-PGRI/2009, tanggal 16 Februari 2009.
Kurikulum KKNI pun berusaha dengan baik di susun oleh Universitas PGRI Palembang, termaksudlah Mata Kuliah Wajib salah satunya yaitu Kewirausahaan.

\section{Diskripsi Pelaksanaan Penelitian}

Penelitian ini dilakukan di Universitas PGRI Palembang berlokasi di Jalan Jend A Yani Lrg.Gotong Royong 9/10 Ulu Palembang. Sampel dalam penelitian ini berjumlah 51 Mahasiswa Program Studi Pendidikan Akuntansi Universitas PGRI Palembang tahun Akademik 2017/2018. Penelitian dilakukan dengan cara membagikan angket sarana prasarana pendidikan kepada responden. Setelah dibagikan responden mengisi jawaban sesuai dengan pernyataan responden.

\section{Motivasi Berwirausaha Mahasiswa di Universitas PGRI Palembang}

Minat dan Motivasi berwirausaha perlu dan harus ditumbuh kembangkan di kalangan masyarakat termasuk mahasiswa karena memiliki manfaat banyak sekali antara lain menambah daya tampung tenaga kerja, sehingga dapat mengurangi pengangguran dan meningkatkan pendapatan masyarakat, meningkatkan produktivitas, dengan menggunakan metode baru, maka wirausaha dapat meningkatkan produktivitasnya. Kemudian meningkatkan pertumbuhan ekonomi dan menciptakan pekerjaan. 
Dorongan membentuk wirausaha juga datang dari teman pergaulan, lingkungan famili, dan sahabat. Mereka dapat berdiskusi tentang ide wirausaha, masalah yang dihadapi dan cara-cara mengatasi masalahnya. Pendidikan formal dan pengalaman bisnis kecil-kecilan yang dimiliki oleh seseorang dapat menjadi potensi utama untuk menjadi wirausaha yang berhasil. Beberapa motivasi yang mendorong seseorang berwirausaha antara lain pertama, alasan keuangan, yaitu untuk mencari nafkah, untuk menjadi kaya, untuk mencari pendapatan tambahan. Kedua, alasan sosial, yaitu untuk memperoleh gengsi/status untuk dapat dikenal dan dihormati, agar dapat bertemu dengan orang banyak. Kemudian ketiga, alasan pelayanan yaitu untuk memberi pekerjaan pada masyarakat, untuk membantu ekonomi masyarakat, untuk masa depan anak dan keluarga dan keempat alasan pemenuhan diri, yaitu untuk menjadi atasan mandiri, untuk menghindari ketergantungan pada orang lain, untuk mencapai sesuatu yang diinginkan, untuk menjadi lebih produktif, untuk menggunakan kemampuan pribadi atau berprestasi.

Bekal ilmu dan kreatifitas mahasiswa yang diperoleh dalam perkulihan dapat dikembangkan dengan berwirausaha. Sehingga mahasiswa dapat membuka lapangan pekerjaan sendiri dan tidak perlu mencari lapangan pekerjaan. Tetapi banyak diantara mahasiswa yang masih enggan atau takut untuk berwirausaha. Hal ini, disebabkan karena mental yang dimiliki mahasiswa. Survey membuktikan bahwa kebanyakan dari mahasiswa yang lebih cenderung memilih atau berkeinginan melamar kerja dikantor sebagai karyawan atau sebagai pegawai. Hal ini mengakibatkan semakin meningkatnya pengganguran dan semakin sedikitnya lapangan pekerjaan yang dibutuhkan.

Untuk itu, banyak pihak yang menyelenggarakan seminar, workshop dan pelatihan tentang wirausaha bagi mahasiswa. Tujuan diselenggarakan hal tersebut adalah:

1. Untuk mendorong minat mahasiswa dalam berwirausaha,

2. Untuk mengembangkan kreatifitas mahasiswa tersebut,

3. Membuka lapangan pekerjaan,

4. Membangun mental bagi mahasiswa yaitu percaya diri, pantang menyerah, mampu bekerja keras, dll,

5. Mengembangkan wirausaha baru yang berpendidikan tinggi,

6. Menciptakan bisnis baru berbasis ilmu pengetahuan, teknologi dan seni.

Sedangkan manfaat yang diperoleh dari berwirausaha adalah:

a. Bagi Mahasiswa

- Memberikan kesempatan untuk terlibat langsung dengan dunia 
kerja sehingga dapat mengembangkan soft-skillnya,

- Menumbuhkan jiwa bisnis

- Memberikan kesempatan langsung untuk terlibat dalam kegiatan nyata di UKM guna mengasah jiwa wirausaha.

b. Bagi Perpendidikan Tinggi

- Meningkatkan kemampuan perpendidikan tinggi dalam pengembangan pendidikan wirausaha.

- Memperat hubungan antara dunia akademis dan dunia usaha, khususnya UKM.

- Membuka jalan bagi penyesuaian kurikulum yang dapat merespon tuntutan dunia usaha.
- Menghasilkan wirausahawirausaha muda pencita lapangan kerja dan calon pengusaha sukses masa depan.

\section{Hasil Penelitian}

\section{Analisis Data dan Angket}

Untuk menganalisis data yang diteliti mengenai motivasi berwirausaha mahasiswa Program Studi Pendidikan Akuntansi peneliti menyusun angket sebanyak 35 item, angket dibagikan pada 51 mahasiswa Pendidikan Akuntansi yang dijadikan sampel penelitian, hasil analisa data yang telah peneliti distribusikan berdasarkan angket yang telah diolah dapat dilihat pada tabel berikut.

Tabel 5. Distribusi Frekuensi Persentase Motivasi Berwirausaha

\begin{tabular}{|l|c|c|c|c|}
\hline No & Kriteria Nilai & F & \% & Kategori \\
\hline 1. & $81-100$ & 22 & 43,14 & Baik sekali \\
\hline 2. & $76-80$ & 26 & 50,98 & Baik \\
\hline 3. & $60-75$ & 3 & 5,88 & Cukup \\
\hline 4. & $55-59$ & - & - & Kurang \\
\hline 5. & $\leq 54$ & - & - & Sangat kurang \\
\hline & Jumlah & 51 & 100 & \\
\hline
\end{tabular}

(Sumber: hasil olahan peneliti)

Dari hasil data Distribusi Frekuensi di atas, dapat disimpulkan bahwa Motivasi mahasiswa Program studi Pendidikan Akuntansi FKIP di Universitas PGRI Palembang sudah
Baik, hal ini dapat dilihat pada kategori Baik Sekali yaitu 43,14\%, Baik yaitu 50,98\% dan Cukup $5,88 \%$. Lebih jelasnya dapat dilihat pada diagram dibawah ini: 


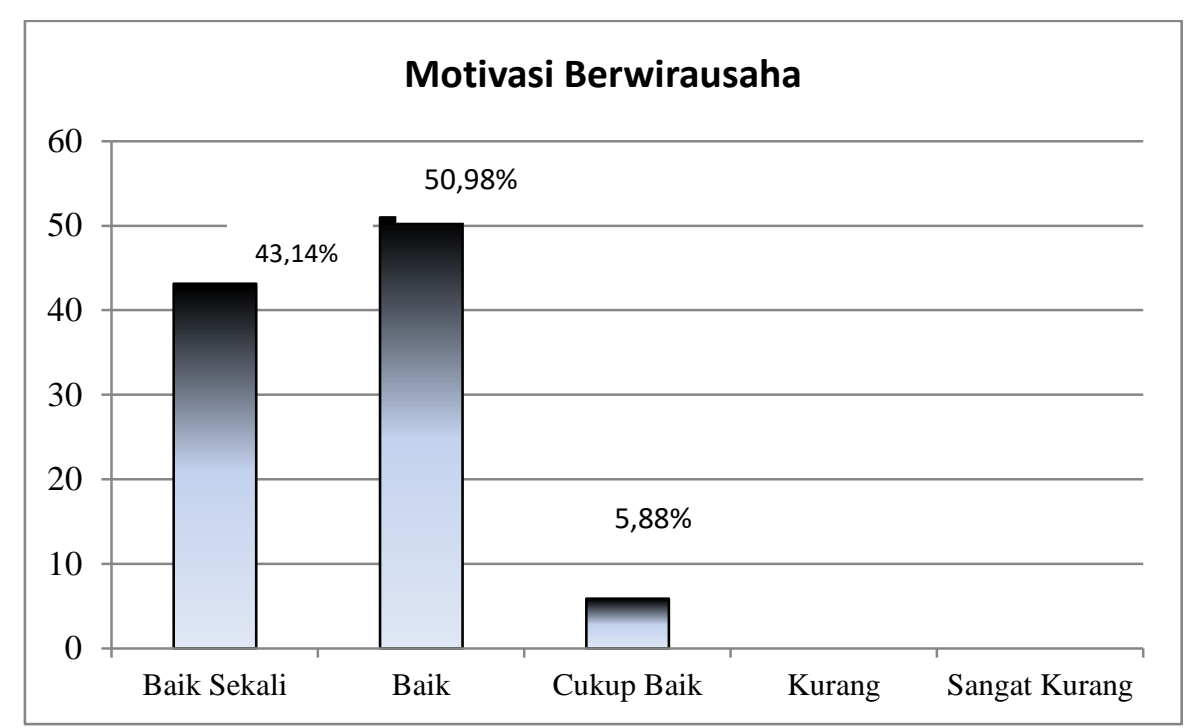

Gambar 1. Distribusi Frekuensi Persentase Motivasi Berwirausaha

\section{Pembahasan}

Berdasarkan hasil Angket peneliti menganalisis tentang motivasi Internal dan Motivasi ekternal yaitu sebagai berikut:

(1) Tanggung jawab mahasiswa dalam mengerjakan tugas kuliah kewiusahaan, berdasarkan hasil 7 daftar pernyataan dari 51 mahasiswa, ada 1 pernyataan negatif 2 orang sangat setuju, 3 orang setuju, 11 orang kurang setuju dan 34 orang tidak setuju, yaitu pernyataan Tugas-tugas berat yang saya hadapi dalam matakuliah kewirausahaan membuat saya tidak bersemangat lagi untuk berwirausaha. Sedangkan 6 daftar pernyataan positif ratarata 17 orang sangat setuju, 31 orang setuju, 2 orang kurang setuju dan 1 orang tidak setuju, dengan persentase sebesar $84,07 \%$ Kategori Sangat Baik.
Jadi dapat disimpulkan, bahwa mahasiswa memiliki tanggung jawab dalam mengerjakan tugas kuliah kewirausahaan hal tersebut terbukti dari pernyataan mahasiswa dengan Indikator pernyataan, Tanggung jawab mahasiswa dalam mengerjakan tugas kuliah kewiusahaan dalam kategori Sangat Baik yaitu sebesar $84,07 \%$.

(2) Melaksanakan tugas kewirausahaan dengan target yang jelas, berdasarkan hasil 6 daftar pernyataan dari 51 mahasiswa, ada 2 pernyataan negatif sangat setuju tidak ada, 3 orang setuju, 19 orang kurang setuju dan 27 orang tidak setuju, yaitu pernyataan terlambar dalam mengumpulkan tugas merupakan hal yang biasa bagi saya dan Biasanya saya keberatan jika diberikan tugas kewirausahaan baru di luar tugas 
rutin, yang sudah direncanakan didalam kontrak perkuliahan. Sedangkan 4 daftar pernyataan positif rata-rata 16 orang sangat setuju, 33 orang setuju, 1 orang kurang setuju dan 1 orang tidak setuju. Jadi dapat disimpulkan, mahasiswa dapat melaksanakan tugas kewirausahaan dengan target yang jelas, hal tersebut terbukti dari pernyataan positif $64,71 \%$ mahasiswa menyatakan setuju dengan, Indikator pernyataan melaksanakan tugas kewirausahaan dengan target yang jelas.

(3) Memiliki tujuan yang jelas dan menantang, berdasarkan hasil 8 daftar pernyataan dari 51 mahasiswa, ada 2 pernyataan negatif sangat setuju 2, 7 orang setuju, 17 orang kurang setuju dan 25 orang tidak setuju, yaitu pernyataan bagi saya, meninggalkan perkuliahan untuk keprntingan pribadi merupakan hal yang biasa dan pernyataan untuk menyelesaikan tugas, saya memilih cara termudah meskipun hasil tidak maksimal. Sedangkan 6 daftar pernyataan positif rata-rata 17 orang sangat setuju, 32 orang setuju, 1 orang kurang setuju dan 1 orang tidak setuju, dengan persentase sebesar $81,86 \%$ Kategori Sangat Baik. Jadi dapat disimpulkan, bahwa dalam belajar kewirausahaan mahasiswa memiliki tujuan yang jelas dan menantang, hal tersebut terbukti dari pernyataan mahasiwa indikator memiliki tujuan yang jelas dan menantang dalam kategori Sangat Baik yaitu sebesar $81,86 \%$.

(4) Ada umpan balik atas hasil belajar kewirausahaan dan selalu berusaha memenuhi kebutuhan belajar kewirausahaan, berdasarkan hasil 5 daftar pernyataan positif dari 51 mahasiswa rata-rata, 18 orang sangat setuju, 31 orang setuju, 2 orang kurang setuju dan 1 orang tidak setuju, dengan persentase sebesar 82,84\% Kategori Sangat Baik. Jadi dapat disimpulkan, bahwa dalam belajar kewirausahaan mahasiswa mengharapkan Ada umpan balik atas hasil belajar kewirausahaan dan selalu berusaha memenuhi kebutuhan belajar kewirausahaan hal tersebut terlihat dari kategori Sangat Baik sebesar $82,84 \%$.

(5) Memiliki rasa senang dalam belajar kewirausahaan dan Selalu berusaha memenuhi kebutuhan belajar kewirausahaan, berdasarkan hasil 4 daftar pernyataan positif dari 51 mahasiswa rata-rata, 14 orang sangat setuju, 35 orang setuju, 2 orang kurang setuju dan tidak setuju tidak ada yang memberikan pernyataan, dengan persentase sebesar 80,88\% Kategori Baik. Jadi dapat 
disimpulkan, bahwa dalam Indikator pernyataan Memiliki rasa senang dalam belajar kewirausahaan dan Selalu berusaha memenuhi kebutuhan belajar kewirausahaan, dalam kategori Baik yaitu sebesar $80,88 \%$.

(6) Selalu berusaha mengungguli orang lain dan Belajar dengan harapan ingin memperoleh penghargaan dari dosen. Berdasarkan hasil 3 daftar pernyataan positif dari 51 mahasiswa rata-rata, 15 orang sangat setuju, 29 orang setuju, 6 orang kurang setuju dan 1 orang tidak setuju, dengan persentase sebesar 78,43\% Kategori Baik. Jadi dapat disimpulkan, bahwa dalam belajar kewirausahaan mahasiswa termotivasi menjadi yang terbaik dalam pelajaran kewirausahaan, hal tersebut terbukti dari pernyataan mahasiswa, Indikator pernyataan Selalu berusaha mengungguli orang lain dan belajar dengan harapan ingin memperoleh penghargaan dari dosen dalam kategori baik yaitu sebesar $78,43 \%$.

(7) Diutamakan prestasi dari apa yang telah dipelajari dan Belajar dengan harapan ingin memperoleh prestasi. Berdasarkan hasil 2 daftar pernyataan positif dari 51 mahasiswa rata-rata, 19 orang sangat setuju, 30 orang setuju, 1 orang kurang setuju dan 1 orang tidak setuju, dengan persentase sebesar $82,84 \%$ Kategori Sangat Baik. Jadi dapat disimpulkan, bahwa dalam proses belajar mengajar matakuliah kewirausahaan mahasiswa sangat mengutamakan dan mengaharapkan prestasi hal tersebut terbukti dari indikator ini dalam kategori Sangat Baik yaitu sebesar $82,84 \%$.

Berdasarkan pernyataan di atas dapat disimpulkan bahwa Motivasi Berwirausaha Mahasiswa pada Program Studi Pendidikan Akuntansi FKIP Universitas PGRI Palembang dalam Kategori Baik/ Tinggi terlihat dari jumlah hasil pernyataan mahasiswa yaitu sebesar 80,79.

\section{KESIMPULAN DAN SARAN}

\section{Kesimpulan}

Berdasarkan hasil analisa data dan pembahasan yang telah diuraikan sebelumnya, maka dapat disimpulkan bahwa: Berdasarkan Pembahansan, yang mendasari motivasi berwirausaha mahasiswa pada Program Studi Pendidikan Akuntansi FKIP Universitas PGRI Palembang dari 7 Indikator ada 4 Indikator dalam kategori Sangat Baik yaitu Indikator Tanggung jawab mahasiswa dalam mengerjakan tugas mata kuliah kewirausahaan sebesar $84,07 \%$, Indikator melaksanakan tugas kewirausahaan dengan target yang jelas sebesar $82,60 \%$, Indikator ada umpan balik atas hasil belajar 
kewirausahaan sebesar $82,84 \%$ dan Diutamakan prestasi dari apa yang telah dipelajari sebesar $82,84 \%$. Jadi indikator yang paling mendasari motivasi berwirausaha mahasiswa Program Studi Pendidikan Akuntansi adalah Indikator Tanggung jawab mahasiswa dalam mengerjakan tugas mata kuliah kewirausahaan yaitusebesar $84,07 \%$.

\section{Saran}

Berdasarkan hasil penelitian maka penulis memberikan saran sebagai berikut:

1) Motivasi Mahasiswa dalam berwirausaha yang sangat tinggi diharapkan di berikan dukungan dan difasilitas oleh Universitas PGRI Palembang, agar Kewirausahaan menjadi salah satu alternatif pekerjaan yang akan ditekuni oleh mahasiswa maupun lulusan (Alumni) .

2) Mahasiswa hendaknya ikut berperan aktif dan ikut berperan dalam persaingan kreatifitas dan ilmu pengetahuan dengan mahasiswa di universitas lain terutama pada PKM kewirausahaan yang di danai oleh kemenRistek Dikti.

3) Penelitian ini dapat menjadi referensi bagi peneliti selanjutnya yang berkaitan dengan motivasi berwirausaha.

\section{DAFTAR PUSTAKA}

Arikunto. 2014. Prosedur Penelitian Suatu Pendekatan Praktik. Jakarta: PT Rineka Cipta

Dhewanto, Wawan. 2013. Intrapreneurship. Bandung: Rekayasa Sains.

Keputusan Menteri Koperasi dan Pembinaan Pengusahan Kecil Nomor 961/KEP/M/XI/1995

Purwanto. 2013. Evaluasi hasil belajar.Yogyakarta: Pustaka Pelajar.

Pusat Kurikulum, Balitbang Depdiknas. 2002. Kurikulum Berbasis Kompetensi. Jakarta : Depdiknas,

Sugiyono. 2014. Metode Penelitian Pendidikan Pendekatan Kuantitatif, Kualitatif, dan $R \& D$. Bandung: Alfabeta. , 2010. Statistik Untuk

Penelitian. Bandung: Alfabeta.

Suryana. 2011. Kewirausahaan: Pedoman Praktis, Kiat dan Proses Menuju Sukses. Jakarta: Salemba Empat

Uno B Hamzah.2007. Teori Motivasi\&Pengukurannya, Analisis di Bidang Pendidikan. Jakarta: Bumi Aksara. 